\title{
Covariance functions under B-spline polynomials to model Polled Nellore cattle growth
}

\section{Funções de covariâncias sob polinômios B-splines para modelagem do crescimento de bovinos Nelore Mocho}

\author{
Diego Helcias Cavalcante ${ }^{1 ;}$ Carlos Syllas Monteiro Luz ${ }^{1 *}$; Marcelo Richelly \\ Alves de Oliveira ${ }^{2}$; Wéverton José Lima Fonseca3; Amauri Felipe Evangelista4; \\ Raimundo Martins Filho ${ }^{5}$; Carlos Henrique Mendes Malhado; \\ Danielle Maria Machado Ribeiro Azevêdo7; Karina Rodrigues dos Santos 8 ; \\ Severino Cavalcante de Sousa Júnior ${ }^{8}$
}

\section{Highlights}

The best fits under the AIC criterion were observed by quadratic and cubic models.

A cubic function improved control of direct additive genetic variance.

Covariance functions under B-spline polynomials in modeling the growth curve.

\section{Abstract}

B-spline functions have been used in random regression models (RRM) to model animal weight from birth to adulthood because they are less vulnerable to common difficulties of other methods. However, its application to model growth traits of Polled Nellore cattle has been little studied. Therefore, this study aimed to evaluate polynomial functions of different orders and segment numbers to model effects associated with the Polled Nellore cattle growth curve. For this purpose, we used 15,148 weight records of 3,115 animals aged between 1 and 660 days and reared in northern Brazil and born between 1995 and 2010. Random effects were modeled using B-spline polynomials. As random effects, we considered the direct and maternal

1 Drs. in Animal Science, Universidade Federal do Piauí, UFPI, Teresina, PI, Brazil. E-mail: diegohelcias@gmail.com; syllaszoot@yahoo.com.br

2 Prof.Dr., Faculty of AnimalScience, MultipleHigherEducation Institute,IESM,Timon, MA,Brazil.E-mail:marcelozootec@ hotmail.com

3 Doctoral Student of the Postgraduate Program in Animal Science, Universidade Estadual do Sudoeste da Bahia, UESB, Itapetinga, BA, Brazil. E-mail: fonsecawjl@gmail.com

4 Dr. in Animal Science, Universidade Federal do Paraná, UFPR, Curitiba, PR, Brazil. E-mail: amaurifelipe17@hotmail.com

5 Prof. Visitor, Universidade Federal do Cariri, UFCA, Juazeiro do Norte, CE, Brazil. E-mail: rmartinsfilho@yahoo.com.br

6 Prof. Dr., Department of Biological Sciences, Universidade Estadual do Sudoeste da Bahia, UESB, Jequié, BA, Brazil. E-mail: carlosmalhado@gmail.com

7 Researcher A, Empresa Brasileira de Pesquisa Agropecuária, EMBRAPA Meio-Norte, Teresina, PI, Brazil. E-mail: danielle.azevedo@embrapa.br

8 Profs. Drs., Faculty of Medicine, Universidade Federal do Delta do Parnaíba, UFDPar, Parnaíba, PI, Brazil. E-mail: sevzoo@yahoo.com.br; krsantos2004@yahoo.com.br

* Author for correspondence

Received: Mar. 31, 2021 - Approved: Sept. 09, 2021 
genetic additives, as well as direct and maternal permanent environments. As fixed effects were included contemporary group, cow age at calving (linear and quadratic) and fourth-order Legendre polynomials to represent average growth curve. The residue was modeled by considering seven age classes. The bestfitted model was the one that considered cubic B-spline functions with four knots for direct additive genetic effects and three knots for maternal genetic, animal permanent environment, and maternal permanent environment effects (C6555). Therefore, covariance functions under B-spline polynomials are efficient and can be used to model the growth curve of Polled Nellore cattle from birth to 660 days of age.

Key words: Genetic parameters. Legendre. Random regression. Segmented polynomials.

\section{Resumo}

Os modelos de regressão aleatória (MRA) aplicando funções B-spline são uma alternativa para modelar pesos do nascimento até a idade adulta dos animais, pois estas funções são menos vulneráveis as dificuldades constantemente observadas em outras metodologias. No entanto, são escassas pesquisas sobre aplicação destas funções sobre as características de crescimento em bovinos Nelore Mocho. Funções polinomiais de diferentes ordens e números de segmentos foram avaliadas na modelagem dos efeitos associados à curva de crescimento de bovinos da raça Nelore Mocho. Foram utilizados 15.148 registros de peso de 3.115 animais com idade entre 1 e 660 dias, criados na região norte do Brasil e nascidos entre 1995 e 2010. Os efeitos aleatórios foram modelados usando polinômios do tipo B-splines. Como efeitos aleatórios, foram considerados os efeitos genéticos aditivo direto e materno e os efeitos de ambientes permanentes direto e materno. Foram considerados como efeitos fixos, os grupos de contemporâneos, a idade da vaca ao parto (efeito linear e quadrático) e os polinômios de Legendre de quarta ordem, representando a curva média de crescimento. O resíduo foi modelado por meio de sete classes distribuídas segundo a idade. O modelo que considerou funções B-splines cúbicas com quatro nós para o efeito genético aditivo direto e três nós para os efeitos genético materno, ambiente permanente animal e ambiente permanente materno (C6555) foi o mais adequado. Concluiu-se que funções de covariâncias sob polinômios B-splines são eficientes e podem ser utilizados como alternativas para modelar a curva de crescimento de bovinos da raça Nelore Mocho do nascimento até 660 dias de idade.

Palavras-chave: Legendre. Parâmetros Genéticos. Polinômios segmentados. Regressão aleatória.

\section{Introduction}

Beef cattle breeding programs are often based on body weight and weight gains at different ages (Portes et al., 2020). In this scenario, random regression models have been extensively used to assess genetic effects on these traits, as they more accurately describe phenotypic and genetic changes over time (Scalez et al., 2018). To fit random regression models, a continuous function that allows describing genetic and environmental changes over time should be implicitly fitted. These functions are traditionally modeled using orthogonal Legendre polynomials (Scalez, Fragomeni, Passafaro, Pereira, \& Toral, 2014; Passafaro, Fragomeni, Gonçalves, Morais, \& Toral, 2016).

Orthogonal Legendrepolynomials have been widely used to properly estimate genetic parameters of beef cattle (Lopes et al., 2012; 
Ferreira et al., 2015; Cavalcante et al., 2020a). However, for very long evaluation times and/ or reduced number of measurements, these polynomial functions can have undesirable effects, such as: (i) need for high-degree polynomials with a significant increase in model convergence time; (ii) inconsistent (co) variance estimation, mainly at curve ends, and (iii) demand for greater computer processing capacity (Cavalcante, Evangelista, Campêlo, Azevêdo, \& Sousa, 2020b).

One alternative to traditional Legendre polynomials is segmented polynomials, which have shown promising results for beef cattle growth modeling (Boligon, Mercadante, Forni, Lôbo, \& Albuquerque, 2012). A major advantage of segmented polynomials is allowing aggregation of several low-degree polynomial segments from specific positions, known as knots, forming a single continuous curve (Cavalcante et al., 2019).

A particular case of segmented polynomials is type B (B-splines), which have aroused the interest of researchers for presenting satisfactory results in modeling of fixed and random effects that make up the mixed model equation (Boligon et al., 2012). The biggest challenge in using these segmented functions is identifying the appropriate number of intervals and position of knots on growth curves (Cavalcante et al., 2020b).

Given the above, this study was aimed to evaluate the goodness of fit of random regression models under B-spline functions and thus the most parsimonious model to estimate genetic parameters of the growth curve of Polled Nellore cattle.

\section{Material and Methods}

\section{Data description}

Data were gathered from herds included in the weight development control system of the Brazilian Association of Zebu Breeders (ABCZ). These herds are reared in the seven states of northern Brazil (Amazonas, Acre, Amapá, Roraima, Rondônia, Pará, and Tocantins).

Contemporary groups included sex, birthyear, birth season, weighingyear, weighing month, farm, and rearing condition. The birth seasons were classified as rainy (December to May) and dry (June to November). The rearing conditions were "pre-weaning" and "postweaning," with a pasture diet.

Initially, data quality control analyses were performed. We excluded weight records of animals over 660 days of age, without a father and/or mother identification, with less than three weight records, from contemporary groups with less than three animals, and data with potential measurement errors (i.e., out of range of \pm 3 standard deviations in the contemporary group). Data editing and consistency analysis were performed using SAS version 9.1 software (SAS Institute Inc., 2004).

After editing, a total of 15,148 weight records from 3,115 animals born between 1995 and 2010 and reared on pasture were available. To improve analysis flow, data were grouped by age as follows: 1 to 15 days, 16 to 20 days, 21 to 25 days, ..., 631 to 645 days, 646 to 660 days, totaling 117 classes. Each group consisted of a 5-day interval except for those at the beginning and end of the curve, in which it was 15 days, given a smaller number of records (Figure 1). 


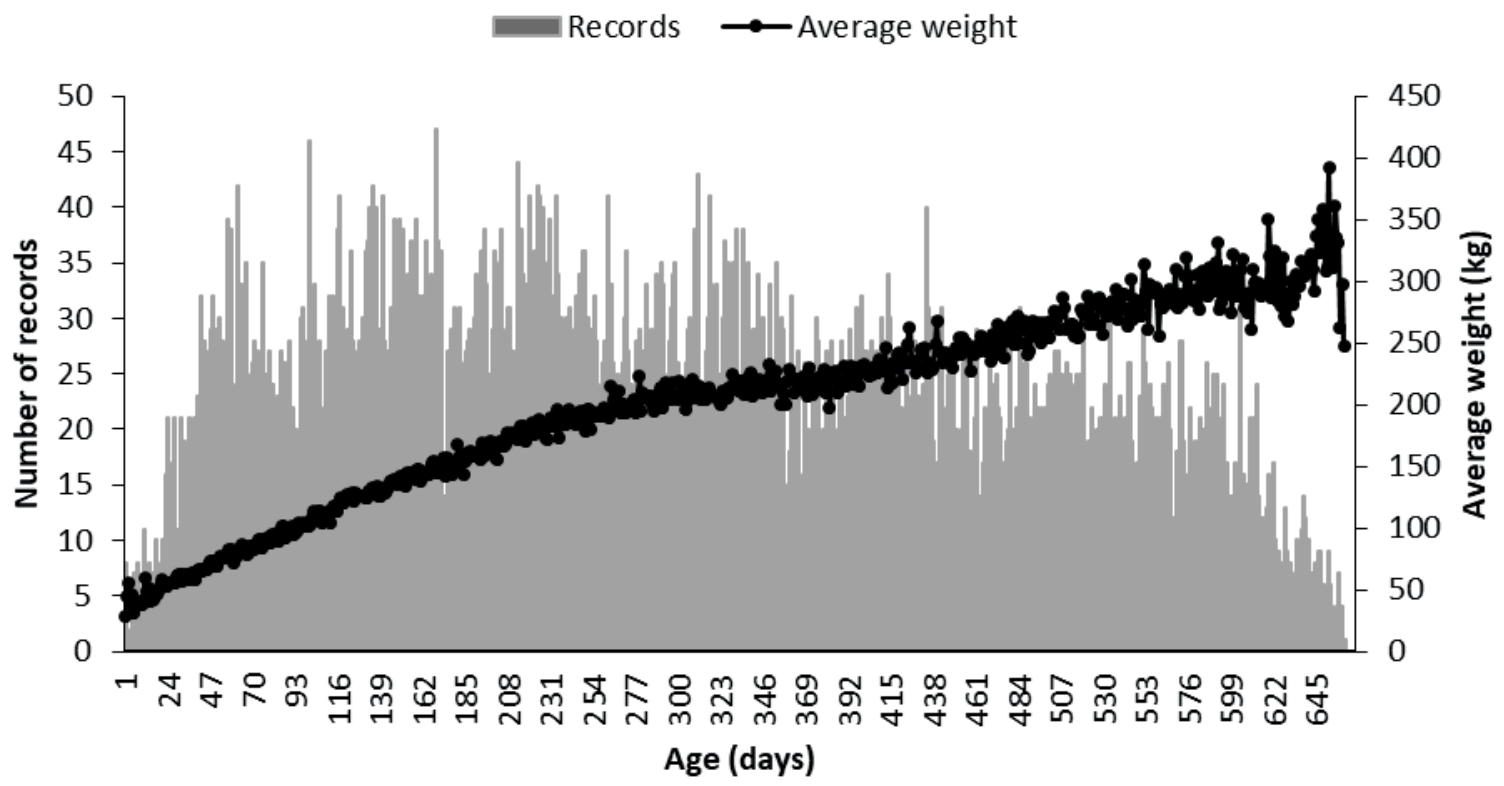

Figure 1. Number of records and average weight per age of Polled Nellore reared in northern Brazil.

Table 1 shows the data structure with the number of observations per animal and pedigree information.

Table 1

Summary of the data structure for Polled Nellore cattle from northern Brazil

\begin{tabular}{|cc|}
\hline Information & Amount \\
\hline Data & 15.148 \\
\hline Animals with observation & 3.115 \\
With 3 observations & 712 \\
With 4 observations & 698 \\
With 5 observations & 549 \\
With 6 observations & 659 \\
With 7 to 10 observations & 497 \\
Breeders & 282 \\
Matrices & 764 \\
Animals in the kinship matrix & 5.678 \\
Contemporary groups & 1.819
\end{tabular}




\section{Analysis description}

Four random effects were included in all models, in addition to residual: two genetic additives (direct and maternal), and two from the permanent environmental (direct and maternal). Random effects were modeled using B-splines functions (Meyer, 2005).

The groups contemporary and mother's age at calving (linear and quadratic effects) within the age group (117 classes) were included as fixed effects. A fourth-order orthogonal Legendre polynomial (cubic) was used to model population average trends. Residue was considered heterogeneous and contained seven classes (detailed above), arranged as follows: 1 ( 1 to 15 days); 2 to 22 (16 to 120 days); 23 to 28 (121 to 150 days); 29 to 46 (151 to 240 days); 47 to 71 (241 to 365 days); 72 to 107 (366 to 545 days); 108 to 117 (546 to 660 days) age classes.

The statistical model can be represented in the matrix form as follows:

$$
\mathrm{y}=X b+Z_{1} a+Z_{2} m+Z_{3} p e+Z_{2} m p e+e
$$

Wherein: $y$ is the vector of observations; $\boldsymbol{b}$ is the vector of the fixed effects; $\boldsymbol{a}$ is the vector of random coefficients for direct additive genetic effect; $\boldsymbol{m}$ is the vector of random coefficients for maternal genetic effect; $\boldsymbol{p e}$ is the vector of random coefficients for permanent animal environment effect; mpe is the vector of random coefficients for maternal permanent environment effect; $\mathbf{e}$ is the vector of residual effects; and X, Z1, Z2, Z3 and $\mathrm{Z} 4$ are the incidence matrices.

The model is based on the following assumptions:

$$
E\left[\begin{array}{c}
a \\
m \\
p e \\
m p e \\
e
\end{array}\right]=\left[\begin{array}{c}
X \beta \\
0 \\
0 \\
0 \\
0
\end{array}\right] ; V\left[\begin{array}{c}
a \\
m \\
p e \\
m p e \\
e
\end{array}\right]=\left[\begin{array}{ccccc}
K_{a} \otimes A & 0 & 0 & 0 & 0 \\
0 & k_{m} \otimes A & 0 & 0 & 0 \\
0 & 0 & K_{p s} \otimes I_{N a} & 0 & 0 \\
0 & 0 & 0 & K_{m p \varepsilon} \otimes I_{N m} & 0 \\
0 & 0 & 0 & 0 & R
\end{array}\right]
$$

Wherein: $K_{a^{\prime}} \quad K_{m^{\prime}} K_{p e^{\prime}}$ and $K_{m p e}$ are the (co)variance matrices between random regression coefficients for direct additive genetic, maternal additive genetic, animal permanent environment, and maternal permanent environment, respectively; $A$ is the matrix of the numerators of the coefficient of kinship between individuals; $\mathbf{I}_{\mathrm{Na}}$ is an identity matrix related to registered animals; $\mathbf{I}_{\mathrm{Nm}}$ is an identity matrix related to mothers with a progeny record; $\otimes$ is the product of Kronecker; $\boldsymbol{R}$ is a diagonal matrix of residual variances. Covariance between direct and maternal additive genetic effects was assumed to be equal to zero (Mota et al., 2013; Barros et al., 2018).

B-spline functions can be defined recursively, with basis functions of degree $p$ $=0$ have values of unity for all points in each interval, and zero otherwise.

For the k-th interval given by knots Tk and $\mathrm{Tk}<\mathrm{T}_{\mathrm{k}+1}$,

$$
\mathrm{B}_{\mathrm{k}, \mathrm{o}}(\mathrm{t})=\left\{\begin{array}{c}
1, \text { if } \mathrm{Tk} \leq \mathrm{t}<\mathrm{Tk}+1, \\
\text { and } \\
0, \text { otherwise }
\end{array}\right.
$$


High-degree basis functions, Bk,p for $p>0$, will then be determined by low-degree basis functions and a range of adjacent intervals between knots. The function can be represented as follows:

$$
\mathrm{B}_{\mathrm{k}, \mathrm{p}}(\mathrm{t})=\frac{t-T_{k}}{T_{k+p}-T_{k}} \mathrm{~B}_{\mathrm{k}, \mathrm{p}^{1}}(\mathrm{t})+\frac{\mathrm{T}_{\mathrm{k}+\mathrm{p}+1}-1}{\mathrm{~T}_{\mathrm{k}+\mathrm{p}+1}-\mathrm{T}_{\mathrm{k}+1}} \mathrm{~B}_{\mathrm{k}+\mathrm{l}, p^{1}}(\mathrm{t})
$$

Linear (L), quadratic (Q) and cubic (C) polynomials for the individual segments were considered, i.e., basis functions of degree $p=$ 1,2 , and 3 .

Polynomials of the same degree were included in the model for all random effects. The $\mathrm{m}$ knots were chosen to divide the age classes at weighing into $\boldsymbol{m}$-1 equidistant intervals.

The number of random regression coefficients to model the trajectory of the linear $(\mathrm{L})$, quadratic $(\mathrm{Q})$, and cubic $(\mathrm{C})$ basis functions were given by $\mathbf{m}, \mathbf{m}+1$, and $\mathbf{m}+2$, respectively. The random regression models (RRMs) were cited as follows: "X ka kap," wherein $X$ corresponds to the degree of the polynomial segment ( $L, Q$, or $C)$, ka and kap are the specific numbers of random regression coefficients for direct and maternal additive genetic and direct and maternal permanent environmental effects, respectively.

The (co)variance components and genetic parameters of the models were estimated by the restricted maximum likelihood (REML) method using the Wombat statistical software (Meyer, 2007). The models were compared using Akaike (AIC) and BayesianSchwarz (BIC) information criteria (Wolfinger, 1993), which can be represented as:

$A I C=-2 \log L+2 p ;$

$B I C=-2 \log L+p \log (N-r)$,
Wherein: $\mathbf{p}$ is the number of model parameters, $\mathbf{N}$ is the total number of observations, $\mathbf{r}$ is the rank of the incidence matrix of fixed effects in the model, and $\log L$ is the logarithm of the restricted maximum likelihood function.

The best model fit was considered the one with the lowest values for $\mathrm{AIC}$ and $\mathrm{BIC}$ criteria. These criteria allow comparing nonhierarchical models and penalizing models with a higher number of parameters, with the $\mathrm{BIC}$ being more rigorous, thus favoring more parsimonious models. After defining the best fit model, Spearman's correlations between predicted breeding values in different age classes were estimated using SAS software, version 9.1 (SAS Institute Inc., 2004).

\section{Results and Discussion}

Table 2 shows the AIC and BIC criteria for the 17 models fitted by B-splines for random effects. The quadratic and cubic models with more segments had the lowest AIC values, with the lowest value for the model C8888, followed by the models Q7777, C8555，C8855，C7777， L6666, and C6555 models. Higher-order models with more segments are more malleable and best fitted to data, but their higher parametrization increases computational demand and hinders model convergence (Cavalcante et al., 2019). Therefore, the BIC criterion was also considered since it more rigorously penalizes parameterized models. 


\section{Table 2}

Model description, number of model parameters (n), the position of knots for direct and maternal genetic effects, number of segments of random effects (s), Akaike (AIC) and Bayesian-Schwarz (BIC) information criteria for random regression models

\begin{tabular}{|c|c|c|c|c|c|c|}
\hline \multirow{2}{*}{ Model } & \multirow{2}{*}{$\mathrm{n}$} & \multicolumn{2}{|c|}{ Knot position } & \multirow[t]{2}{*}{ s } & \multirow[t]{2}{*}{ AIC } & \multirow[t]{2}{*}{$\mathrm{BIC}$} \\
\hline & & Direct genetic effect & Maternal genetic effect & & & \\
\hline L6633 & 61 & $1 ; 24 ; 47 ; 70 ; 93 ; 117$ & $1 ; 24 ; 47 ; 70 ; 93 ; 117$ & $5 ; 5 ; 2 ; 2$ & 87245.3 & 87702.6 \\
\hline L6655 & 79 & $1 ; 24 ; 47 ; 70 ; 93 ; 117$ & $1 ; 24 ; 47 ; 70 ; 93 ; 117$ & $5 ; 5 ; 4 ; 4$ & 87224.3 & 87816.5 \\
\hline L6666 & 91 & $1 ; 24 ; 47 ; 70 ; 93 ; 117$ & $1 ; 24 ; 47 ; 70 ; 93 ; 117$ & $5 ; 5 ; 5 ; 5$ & 87144.4 & 87826.6 \\
\hline Q4444 & 47 & $1 ; 60 ; 117$ & $1 ; 60 ; 117$ & $2 ; 2 ; 2 ; 2$ & 87440.5 & 87792.9 \\
\hline Q5544 & 57 & $1 ; 39 ; 77 ; 117$ & $1 ; 39 ; 77 ; 117$ & $3 ; 3 ; 2 ; 2 ;$ & 87254.0 & 87681.3 \\
\hline Q5555 & 67 & $1 ; 39 ; 77 ; 117$ & $1 ; 39 ; 77 ; 117$ & $3 ; 3 ; 3 ; 3$ & 87221.4 & 87723.6 \\
\hline Q6555 & 73 & $1 ; 30 ; 59 ; 88 ; 117$ & $1 ; 39 ; 77 ; 117$ & $4 ; 3 ; 3 ; 3$ & 87167.3 & 87714.6 \\
\hline Q6655 & 79 & $1 ; 30 ; 59 ; 88 ; 117$ & $1 ; 30 ; 59 ; 88 ; 117$ & $4 ; 4 ; 3 ; 3$ & 87177.8 & 87770.0 \\
\hline Q6666 & 91 & $1 ; 30 ; 59 ; 88 ; 117$ & $1 ; 30 ; 59 ; 88 ; 117$ & $4 ; 4 ; 4 ; 4$ & 87150.3 & 87832.5 \\
\hline Q7777 & 115 & $1 ; 24 ; 47 ; 70 ; 93 ; 117$ & $1 ; 24 ; 47 ; 70 ; 93 ; 117$ & $5 ; 5 ; 5 ; 5$ & 87124.0 & 87986.2 \\
\hline C6555 & 73 & $1 ; 39 ; 77 ; 117$ & $1 ; 60 ; 117$ & $3 ; 2 ; 2 ; 2$ & 87145.9 & 87693.2 \\
\hline C6655 & 79 & $1 ; 39 ; 77 ; 117$ & $1 ; 39 ; 77 ; 117$ & $3 ; 3 ; 2 ; 2$ & 87157.2 & 87749.5 \\
\hline C6666 & 91 & $1 ; 39 ; 77 ; 117$ & $1 ; 39 ; 77 ; 117$ & $3 ; 3 ; 3 ; 3$ & 87173.8 & 87856.0 \\
\hline C7777 & 115 & 1; 30; 59; 88; 117 & $1 ; 30 ; 59 ; 88 ; 117$ & $4 ; 4 ; 4 ; 4$ & 87140.8 & 88002.9 \\
\hline C8555 & 85 & $1 ; 24 ; 47 ; 70 ; 93 ; 117$ & $1 ; 60 ; 117$ & $5 ; 2 ; 2 ; 2 ;$ & 87135.2 & 87772.4 \\
\hline C8855 & 103 & $1 ; 24 ; 47 ; 70 ; 93 ; 117$ & $1 ; 24 ; 47 ; 70 ; 93 ; 117$ & $5 ; 5 ; 2 ; 2$ & 87136.6 & 87908.8 \\
\hline C8888 & 139 & $1 ; 24 ; 47 ; 70 ; 93 ; 117$ & $1 ; 24 ; 47 ; 70 ; 93 ; 117$ & $5 ; 5 ; 5 ; 5 ;$ & 87056.0 & 88098.0 \\
\hline
\end{tabular}

Table 2 also shows that the models Q5544, C6555, and L6633 had the lowest BIC values. Thus, the best fit model showing the lowest $\mathrm{AIC}$ and $\mathrm{BIC}$ values was the $\mathrm{C} 6555$, with a total of 75 parameters. This model, therefore, is the most suitable to describe variances in the direct additive and maternal genetic random effects, in addition to animal and maternal permanent environmental effects. Although cubic B-spline models require several parameters, the $\mathrm{C} 6555$ model had a suitable fit. Also, despite the low BIC values of the Q5544 and L6633, these models had high AIC values, respectively, 87254.0 and 87245.3.

The direct additive genetic variance ( $\mathrm{s}^{2} \mathrm{a}$ ) estimated by models C6555, Q5544, and
L6633 showed an upward trend throughout the trajectory (Figure 2). Ferreira et al. (2017) verified a similar behavior in Guzera cattle. From class 100 (515 days of age) onwards, additive genetic variance estimates increased sharply, probably due to less information. The same was also reported by Araújo et al. (2016).

The linear model L6633 showed the highest additive genetic variances compared to the others, mainly in the middle (Q5544 and C6555) and end (C6555) of the growth curve. Despite the genetic effects being composed of 5 segments, the linear function could not properly model weight (co)variance changes with age, resulting in a rough fit. In contrast, the quadratic models C6555 and Q5544 showed 
smoother curves with the same growth trend, but with unexpected growth towards the ends of the curve. Therefore, the cubic function was the one that allowed better control of direct additive genetic variance.
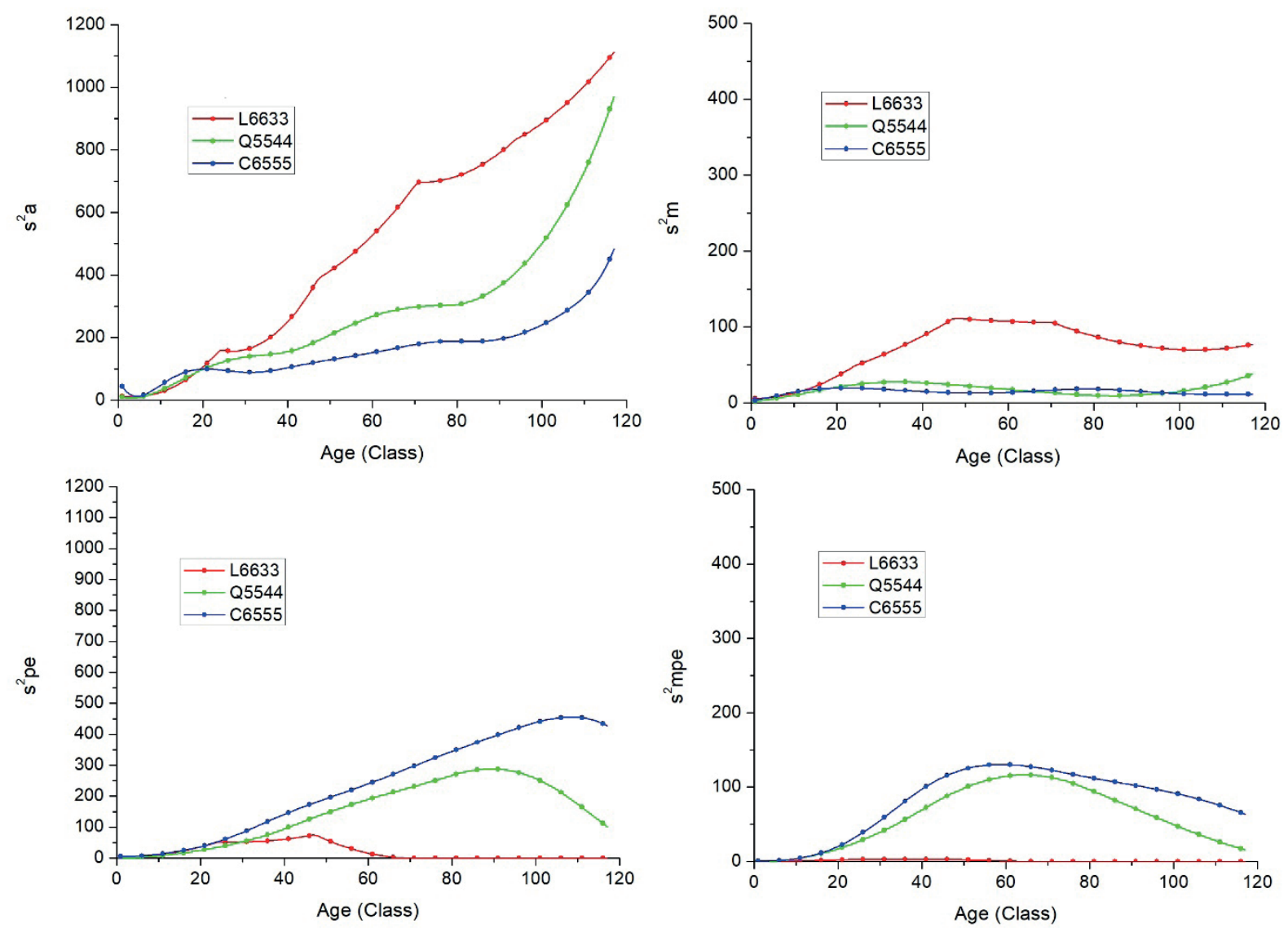

Figure 2. Estimates of direct genetic additive variance $\left(s^{2} a\right)$, maternal genetic variance $\left(s^{2} \mathrm{~m}\right)$, direct permanent environment ( $\left.s^{2} p e\right)$, and maternal permanent environment ( $s^{2} \mathrm{mpe}$ ) components for the B-spline models L6633, Q5544, and C6555.

Maternal genetic variance $\left(\mathrm{s}^{2} \mathrm{~m}\right)$ obtained by the models C6555 and Q5544 had a similar trend with small oscillation at the beginning of the curve, followed by low variance towards the end (Figure 2). Cavalcante et al. (2019) reported similar behavior in Polled Nellore cattle from birth to 660 days of age. Conversely, maternal genetic variance by the linear model showed increasing values up to the 50th age class (255 to 260 days of age), tending to decline at older ages, and increasing again at the end of the growth curve. Most studies that include maternal effects in growth analyses have generally shown reductions after weaning, indicating their low importance (Scalez et al., 2018; Cavalcante et al., 2019; Portes et al., 2020).

As for animal permanent environment effect ( $\left.s^{2} p e\right)$, estimates increased with animal age, with similar curve patterns between cubic (C6555) and quadratic (Q5544) models (Figure 2). The linear model (L6633) showed a growth 
behavior of $s^{2}$ pe from birth to 120 days of age (class 22), followed by a decline up to 305 days (class 60), where it stabilized close to zero and remained until the end of the curve. growth. The abrupt results after 305 days of age by the $\mathrm{L} 6633$ model are biologically inconsistent, which supports the hypothesis that such model is inefficient to model the $s^{2}$ pe of the population under study.

The highest maternal permanent environment variance ( $\mathrm{s}^{2} \mathrm{mpe}$ ) was estimated by the 66555 model (130.4), which was close to 240 days of age (47th age class), followed by a reduction, and then becoming null at advanced ages (Figure 2). This behavior was expected given little influence from the maternal environment after weaning. A similar

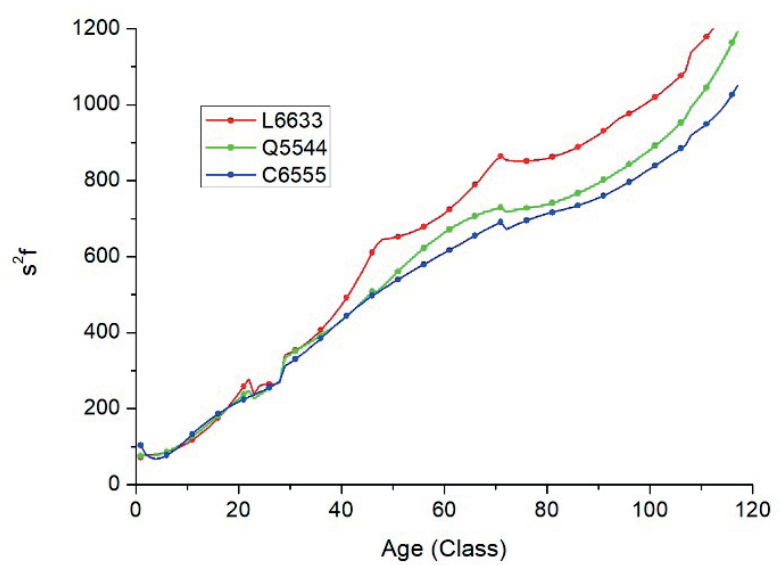

result was obtained by Araújo et al. (2016) in Nellore cattle. The model L6633, however, showed a slightly linear behavior and close to zero during the entire evaluation period, without any biological justification therefor.

Residual variance estimates $\left(\mathrm{s}^{2} \mathrm{e}\right)$ were similar among models, with lower values at the beginning of the growth curve (Figure 3). The linear model practically zeroed variance estimates from the 23rd to 28th age class (120 to 150 days of age). Lower residual variance in pre-weaning may be due to homogeneity in the calf rearing environment when calves are highly dependent on the maternal environment. This, although genetic for the mother, is an environmental factor for calves (Ferreira et al., 2017).

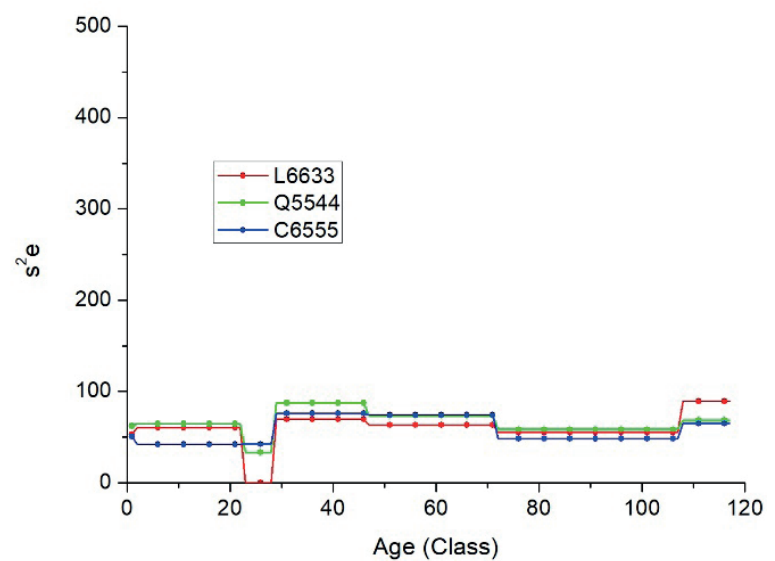

Figure 3. Estimates of residual $\left(s^{2} e\right)$ and phenotypic $\left(s^{2} f\right)$ variance components for the models L6633, Q5544, and C6555.

For phenotypic variance $\left(s^{2} f\right)$, models had similar fits, showing gradual growth with age and more accentuated increases at older ages (Figure 3). This is standard behavior for beef cattle, as reported by Teixeira et al (2018) and Portes et al. (2020) in Nellore cattle. These authors reported that $\mathrm{s}^{2} \mathrm{f}$ growth may be due to increases in genetic variance throughout the growth curve.
Heritability estimates by the models L6633, Q5544, and C6555 had a similar pattern up to 110 days of age (20th grade) (Figure 4). At the beginning of the growth curve ( 1 to 100 days of age), the estimates varied widely $(0.18$ to 0.48$)$ among these models. Lopes et al. (2012) observed the same behavior. From 110 days of age (20th grade), the models L6633 and Q5544 had 
heritability estimates higher than those of the model C6555 (Figure 4), reaching 0.87 and 0.81 at the end of the evaluated period (650 to 660 days of age). This indicates implausible results, out of a realistic aspect. Therefore, such models were inefficient in describing random effects and permanent environment variances for the body weight of the animals evaluated in this study. In contrast, the C6555 model had coherent and moderate heritability estimates (0.42 and 0.46). Thus, the studied population has sufficient genetic variability for a plausible genetic gain when breeding is based on individual animal information.

Animal permanent environment variance $\left(\mathrm{c}^{2}\right)$ as a proportion of phenotypic variance estimated by the models Q5544 and $\mathrm{C6555}$ followed the same trend (Figure 4). However, the model L6633 had an inconsistent behavior, with estimates close to zero from 305 days of age (60th grade). This result is explained by the animal permanent environment effect $\left(s^{2} p e\right)$, which remained equal to zero after 305 days of age.
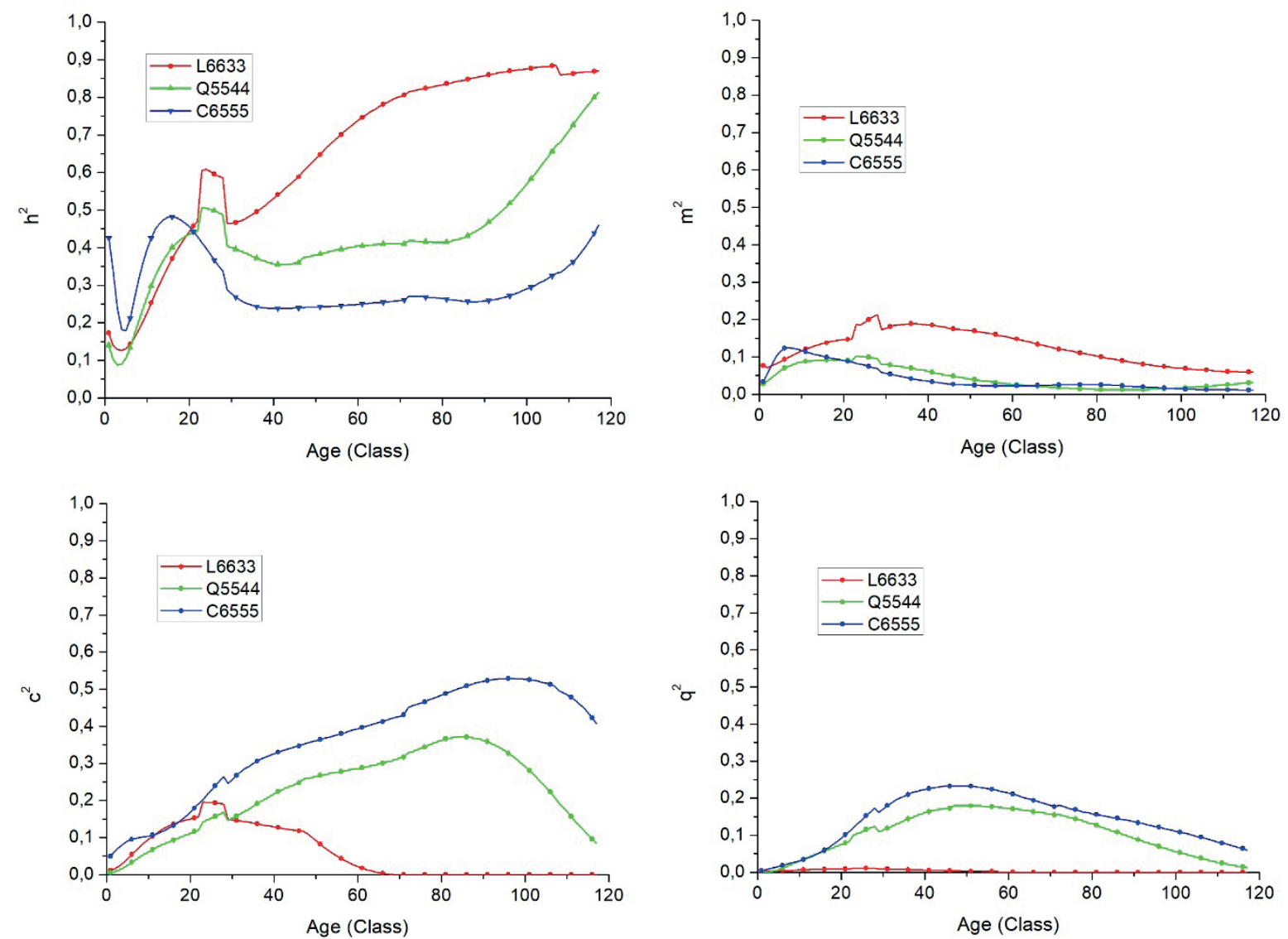

Figure 4. Estimates of direct heritability $\left(\mathrm{h}^{2}\right)$, maternal heritability $\left(\mathrm{m}^{2}\right)$, and animal $\left(\mathrm{c}^{2}\right)$ and maternal $\left(q^{2}\right)$ permanent environmental variances as a proportion of total phenotypic variance obtained by random regression models. 
Similarly, maternal permanent environment variance $\left(\mathrm{q}^{2}\right)$ as a proportion of phenotypic variance estimated by the models Q5544 and C6555 followed the same trend (Figure 4), with a gradual growth until weaning (47th age class) and thereafter a continuous decline (Figure 4). This phenomenon can be explained by phases of maternal behavior, in which heifer contribution to calf phenotype began to decline near the 47th degree (weaning time), which is biologically acceptable since offspring are highly dependent on maternal care in the first days of life (Ferreira et al., 2017). Boligon et al. (2012) described a similar behavior for beef cattle, but with effect reduction after 800 days of age.

Based on the results of all models, model $\mathrm{C} 6555$ was the one to best explain changes in genetic parameters throughout the growth curve. Besides the lowest AIC and
BIC values, this model also had heritability variance estimates consistent with the literature (Oliveira et al., 2017; Teixeira et al., 2018). Unlike our results, Boligon et al. (2012), using B-spline functions to model growth of Nellore cattle from birth to 3920 days of age, observed that the quadratic B-spline model (Q4433) was the best fit to the evaluated data.

Figure 5 shows Spearman's correlation among direct additive breeding values by the $\mathrm{C6555}$ model. In general, correlations between breeding values tended to increase when they are predicted at closer ages (age classes), with a downward trend at more distant ages. The correlation of breeding values was moderate $(0.40)$ between weaning (47th class) and mature (100th class) animals. Therefore, selecting animals by weight at 240 days of age implies choosing the best animals at 510 days of age.

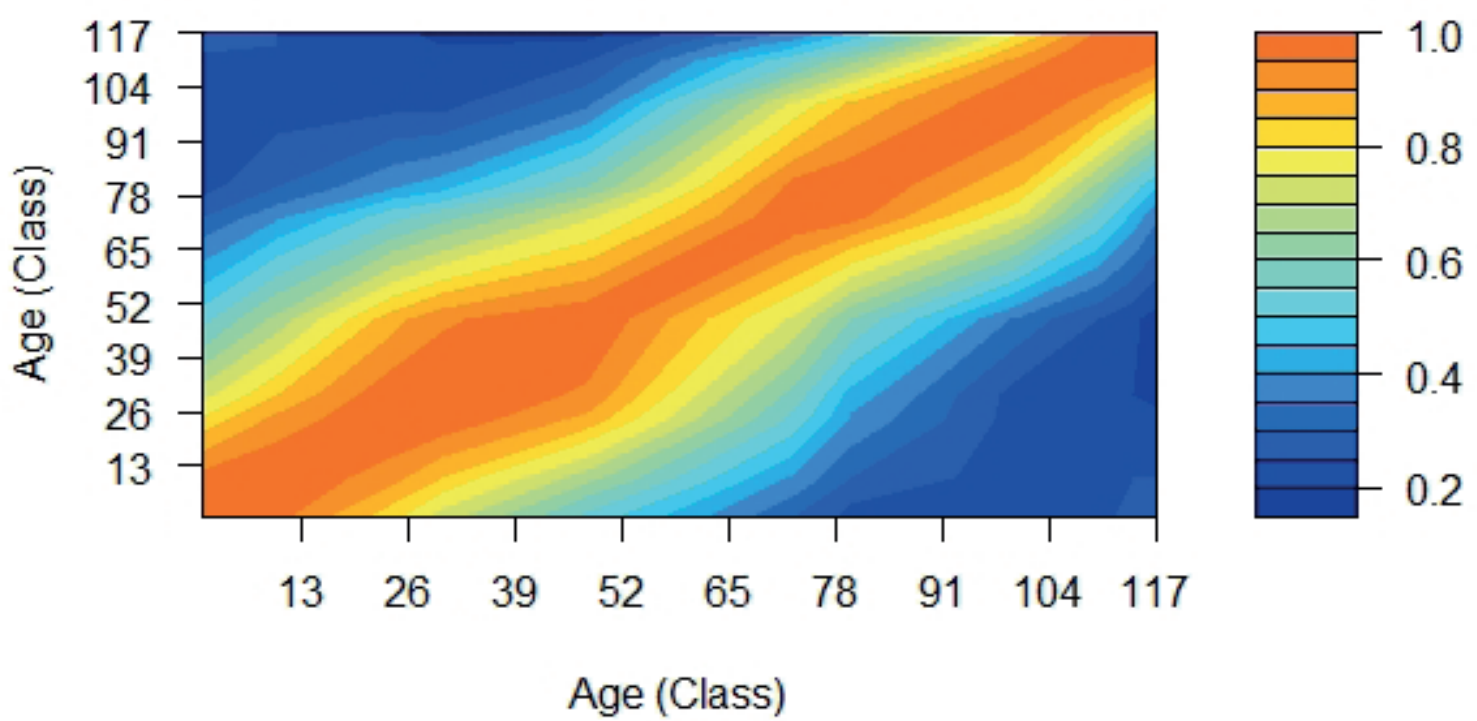

Figure 5. Spearman correlation for direct additive genetic values obtained in different age classes by the model $\mathrm{C} 6555$. 


\section{Conclusion}

Based on the evaluated dataset and fit criteria, the cubic B-spline model (C6555) was the most suitable to describe variances in random direct additive genetic and maternal effects, in addition to permanentenvironmental animal and maternal effects on body weight of Polled Nellore cattle from birth to 660 days of age. Furthermore, additive genetic variation in body weight is sufficient for satisfactory responses to breeding programs, especially up to 270 days of age (class 52).

\section{Acknowledgments}

To the Brazilian Association of Zebu Breeders (ABCZ), Coordination for Improvement of Higher Education Personnel (CAPES), and Graduate Program in Animal Science at the Federal University of Piauí (UFPI).

\section{References}

Araújo, C. V., Nehls, W. F., Laureano, M. M. M., Zubler, R., Lôbo, R. B., Figueiredo, L. G. G.,... Bezerra, L. A. F. (2016). Modelos de regressão aleatória para características de crescimento de bovinos da raça Nelore do Estado de Mato Grosso. Arquivo Brasileiro de Medicina Veterinária e Zootecnia, 68(2), 448-456. doi: 10.15 90/1678-4162-8340

Barros, I. C. D., Mota, R. R., Silva, L. P. D., Carneiro, P. L. S., Martins, R., \& Malhado, C. H. M. (2018). Avaliação genética do crescimento de bovinos Nelore Mocho, por meio de modelos de multicaracterísticas1. Revista Ceres, 65(5), 402-406. doi: 10.1590/0034737X201865050004
Boligon, A. A., Mercadante, M. E. Z., Forni, S., Lôbo, R. B., \& Albuquerque, L. G. (2012). Random regression analyses using B-spline functions to model growth of Nellore cattle. Animal, 6(2), 212-220. doi: $10.1017 / S 1751731111001534$

Cavalcante, D. H., Evangelista, A. F., Campêlo, J. E. G., Azevêdo, D. M. M. R., \& Sousa, S. C., Jr. (2020b). Funções de covariâncias sobre polinômios B-splines para modelagem do crescimento de bovinos de corte: revisão. Medicina Veterinária (UFRPE), 14(1), 5763. doi: 10.26605/medvet-v14n1-3714

Cavalcante, D. H., Sousa, S. C., Jr., Silva, L. P., Malhado, C. H. M., Martins, R., Fº, Azevêdo, D. M. M. R., \& Campêlo, J. E. G. (2020a). Fitting of fixed regression curves with different residual variance structures for Nellore cattle growth modeling. Semina: Ciências Agrárias, 41(2), 545-558. doi: 10.5433/1679-0359.2020v41n2p545

Cavalcante, D. H., Sousa, S. C., Jr., Silva, L. P., Malhado, C. H. M., Martins, R., Fo., Campêlo, J. E. G., \& Santos, K. R. (2019). Covariance function of Legendre polynomials for the modeling of Polled Nellore cattle growth in northern Brazil. Semina: Ciências Agrárias, 40(2), 781-792. doi: 10.5433/1679-0359.2019v40n2p781

Ferreira, J. L., Bresolin, T., Lopes, F. B., Garcia, J. A. S., Nepomuceno, L. L., Schmidt, A. B., \& Lôbo, R. B. (2017). Modelos de regressão aleatória para característica de crescimento em bovinos da raça Guzerá. Ciência Animal Brasileira, 18(1), 1-12. doi: 10.1590/1089-6891v18e-39566

Ferreira, J. L., Lopes, F. B., Pereira, L. S., Nepomuceno, L. L., Garcia, J. A. S., Lôbo, R. B., \& Sainz, R. D. (2015). Estimação de componentes de (co) variâncias para 
características de crescimento em bovinos Nelore criados no Trópico Úmido do Brasil por meio de regressão aleatória. Semina: Ciências Agrárias, 36(3), 17131724. doi: 10.5433/1679-0359.2015v36 n3p1713

Lopes, F. B. Magnabosco, C. U., Paulini, F., Silva, M. C., Miyagi, E. S., \& Lôbo, R. B. (2012). Analysis of longitudinal data of Nellore cattle from performance test at pasture using random regression model. Springer Plus, 1(49), 1-7. doi: 10.1186/2193-1801$1-49$

Meyer, K. (2005). Estimates of covariance functions for growth of Angus cattle from random regression analyses fitting B-spline functions. Proceedings of the Association for Advancement of Animal Breeding Genetics, 16(1), 52-55.

Meyer, K. (2007). WOMBAT - A tool for mixed model analyses in quantitative genetics by restricted maximum likelihood (REML). Journal of Zhejiang University Science B, 8(11), 815-821. doi: 10.1631/jzus.2007. B0815

Mota, R. R., Lopes, P. S., Marques, L. F. A., Silva, L. P. D., Resende, M. D. V. D., \& Torres, R. D. A. (2013). The influence of animals from embryo transfer on the genetic evaluation of growth in Simmental beef cattle by using multi-trait models. Genetics and Molecular Biology, 36(1), 43-49. doi: 10. 1590/S1415-47572013005000008

Oliveira, M. R., Azevêdo, D. M., Malhado, C., Pires, L., Martins, R., \& Sousa, S. (2017). Weight evaluation of Tabapuã cattle raised in northeastern Brazil using randomregression models. Arquivo Brasileiro de Medicina Veterinária e Zootecnia, 69(2), 457-464. doi: 10.1590/1678-4162-9070
Passafaro, T. L., Fragomeni, B. O., Gonçalves, D. R., Morais, M. M., \& Toral, F. L. B. (2016). Genetic analysis of body weight ina Nellore cattle herd. Pesquisa Agropecuária Brasileira, 51(2), 149-158. doi: 10.1590/ S0100-204X2016000200007

Portes, J. V., Cyrillo, J. N. D. S. G., El Faro, L., Mercadante, M. E. Z., Almeida Teixeira, R. de, \& Dias, L. T. (2020). Evaluation of body weight and hip height in Nellore cows in a tropical environment. Livestock Science, 233, 103953. doi: 10.1016/j.livsci.2020.103953

Sas. Institute Inc., SAS/STAT ${ }^{\circledR}$. (2004). User's Guide, Version 9.1, Cary, NC: SAS Institute Inc.

Scalez, D. C. B., Fragomeni, B. O., Passafaro, T. L., Pereira, I. G., \& Toral, F. L. B. (2014). Polynomials to model the growth of young bulls in performance tests. Animal, 8(3), 370-378. doi: 10.1017/S175 1731113002334

Scalez, D. C. B., Fragomeni, B. de O., Santos, D. C. C. D., Passafaro, T. L., Alencar, M. M. D., \& Toral, F. L. B. (2018). Random regression models with B-splines to estimate genetic parameters for body weight of young bulls in performance tests. Revista Brasileira de Zootecnia, 47(20150300), 2-9. doi: $10.1590 /$ rbz4720150300

Teixeira, B. B., Mota, R. R., Lôbo, R. B., Silva, L. P., Carneiro, A. P. S., Silva, F. G.,... Silva, F. F. (2018). Genetic evaluation of growth traits in nellore cattle through multi-trait and random regression models. Czech Journal of Animal Science, 63(6), 212221. doi: 10.17221/21/2017-CJAS

Wolfinger, R. (1993). Covariance structure selection in general mixed models. Communications in Statistics. Simulation and Computation, 22(4), 1079-1106. doi: 10.1080/03610919308813143 
